\title{
Splenectomy in combination with omentorenopexy as a method of treatment of ascites as a result of hepatic and under hepatic forms of portal hypertensia
}

\author{
Salivon V. ${ }^{1}$, Sukhonos V. ${ }^{2}$ \\ ${ }^{1,2}$ National university of biological resources and nature management of Ukraine, \\ Colonel Potekhina, Str., 16, Kyiv, 03041, Ukraine; \\ e-mail: 1'salivon2886@gmail.com
}

The purpose. To assess efficiency of splenectomy in combination with omentorenopexy as a method of surgical treatment of ascites at the dogs, caused by hepatic and under hepatic forms of portal hypertensia. Methods. Omentorenopexy, splenectomy, auto-reinfusion of ascitic fluids, infusion of $10 \%$ albumin of a man, conservative treatment (spironolactone and furosemide). Results. Simultaneous splenectomy and omentorenopexy in combination to preoperative correction of the level of general blood protein positively influences decrease of manifestations of ascites. Conclusions. Surgical correction of portal hypertensia and ascites by the combined operation which consists in simultaneous splenectomy and omentorenopexy, takes precedence over conservative treatment in long-term perspective. Correction of the level of general blood protein at dogs with ascites before surgical treatment positively influences the state of an organism in the early postoperative period that is manifested first of all by lowering of lethality.

Key words: ascites, portal hypertensia, splenectomy, omentorenopexy, auto-reinfusion, ascitic fluid, total protein of blood.

\section{Introduction.}

The urgency of the problem of surgical treatment of patients with the syndrome of portal hypertension and ascites seems to be quite significant at present. Recently, there is a marked increase in the number of sick dogs with hepatic pathology and signs of portal hypertension. Usually in veterinary clinics, sick dogs with symptoms of ascites come already with severe stages of the disease, in large part after a long delay of the host. Ascites usually appears at an advanced stage of the disease in $85 \%$ of cases. Mortality since the onset of ascites is $42-73 \%$ during the first six months, and only $20 \%$ of patients live longer than 1 year. The average life expectancy in these diseased animals is from 1 to 5 months [1] .

Mechanisms of appearance of ascites are very complex, but in its pathogenesis plays an important role of abdominal and visceral disorders of blood circulation and hypoproteinemia [2 ] .

One of the main causes of ascites development in dogs is portal hypertension, however. The syndrome of portal hypertension is called an increase in the porosity gradient of blood pressure above $10 \mathrm{~mm}$. mercury column, which is accompanied by effervescence of a free fluid in the abdominal cavity [3]. In accordance with the localization of the obstacles to the outflow of blood secreted hepatic, underhepatic and overhepatic forms of portal hypertension. In addition, there is a negative pessimism of doctors regarding this group of patients, since conservative treatment is not effective enough and surgical intervention is not developed. Therefore, specified factors and determine relevance and treatment of ascites due to liver and obstructive form of portal hypertension by using splenectomy in combination with omentorenopekxy.

Almost all surgical methods for treating ascites and portal hypertension syndrome in humane medicine are based on the translated direction of blood flow from the portal vein pool to the cavity of the vein immediately [4] .

Correction movement in the blood can be done, as in the middle of the pairs of liver parenchyma - with intra- hepatic bypass, and from the organs of the abdominal cavity (Splenorenal shunts, shunts portosystemni etc.) [5]. We set ourselves the goal of developing a method of surgical intervention that may be further applied in veterinary practice. The following factors were taken into account : technical ease of surgical operation, since most of the veterinary surgeons do not possess angio-surgical technique. Also , 
operative the intervention was not foreseeable significant material costs. At the same time, our proposed method should be effective and give a fairly stable and stable after the operating result.

Analysis the latter research and publications. Evolution methods treatment of portal hypertension syndrome complicated with ascites lasts for several decades. In 1877 these N.V. Eck on the base of their own work on the formation of portal anastomoses in eight dogs said that this operation can be successfully performed in humans, despite the fact that seven out of eight dogs were killed. . In 1892, these I.P. Pavlov in the experiment has imposed portocaval anastomosis " side-to - side ", which allowed to reduce intoxication and to increase duration life dogs [ 6 ] . In the clinical practice portocaval anastomosis for the first time found application in the patient human eye in 1903 when it was performed by N. Vidal by type of operation Ekk well. Splenectomy, omenorenopexy, and various options operations entered the practice with the first one quarter of the XX century. Portoka Portal shunting has established itself in clinical practice in the 40s and the next the leading methods of surgical correction of steel total shunting, partial bypass and selective decompression varicose th widening of the veins [7 ]. In 1969 , J. Rosh and co-authors have posted the results of the first experiments formation shunts between the bottom hollow and portal veins and animals "without use open it surgical technology [8 ] .

Splenectomy is enough widespread interference from the middle the past century, what was explained positive influence her on the portal pressure.

In our time, the proposed is great number operations and theirs modifications ( about 200) for treatment patients with portal hypertension and ascites syndrome. Results operations are often disappointing, but most the severity of the patients after not susceptible to surgical treatment [9] .

In the analysis literature we did not find clear answer the question of necessity ness delete spleen (with portosystemic bypass surgery or without it ), and that skin description possible complications of splenectomy.

In a row researches the latter decade I established role and meaning hypoproteinemia, as one of the major factors adverse surgical outcome forging patients with portal hypertension syndrome and ascites. Auto re publications note that hypoproteinemia Hold always accompanied by portal hypertension syndrome that requires additional enter the day albumin for her correction [10 ] . In this regard, necessity testing of splenectomy in combination with omenenterenopexy, as a method of treating ascites as a result of hepatic and under hepatic forms of portal hypertension in a practical veterinary does not cause medicine doubts.

The purpose of the study. The purpose of our study is to evaluate the effectiveness of splenectomy in conjunction with omenenterenopexy, as a method of surgical treatment of ascites in dogs caused by hepatic and under hepatic forms of portal hypertension.

Methods and results of research. The research was conducted on the basis of the clinic of veterinary medicine "Four paws" in Kyiv. Total research was tested on 20 patients $\mathrm{s}$ dog $\mathrm{s}$ different ages (7 to 10 years), different species and weighing 15 to $45 \mathrm{~kg}$ with the diagnosis of hepatic and obstructive th form of portal hypertension, which was delivered in just a ohoyu ultrasound dos tracking

To evaluate this method of surgical correction of ascites in dogs, we created 3 experimental animal groups.

The first group included sick dogs, which had been performed omenenterenopexy and splenectomy without preoperative correction of the total blood protein level (4 dogs).

The second group consisted of sick dogs with omenorenopexy and splenectomy with preoperative correction of the total blood protein level by autoreinfusion of ascitic fluid (6 dogs) and infusion of $10 \%$ albumin (5 dogs).

The third group included dogs that were prescribed conservative treatment in the form of the use of diuretics - spironolactone and furosemide (5 dogs) .

The method of autorefusion of ascites fluid consists in the intravenous administration of it as a result of the prior collection of the same animal and the study.

The ascites liquid collection was carried out in the operating room in the ove of adherence to the rules of asepsis and antiseptics that precede the laparocentesis. Dogs fixed on the right side, the puncture site was cut off and disinfected, and $0,5 \%$ of novocaine solution was painfully patinated. The point of the puncture was the area of the navel slightly shifted to the right.

Peripheral venous catheter size $16 \mathrm{G}$ was injected perpendicularly to the skin at a depth of $1-3 \mathrm{~cm}$. When the catheter got into the abdominal cavity in the cannula appears needle drop ascites fluid. The needle was 
removed, the end of the cannula was attached to the rubber tube for transfusion of solutions, which was attached to the sterile container. After taking the ascitic fluid immediately after examination, an intravenous drip infusion was injected into the same animal. The infusion rate was $5 \mathrm{ml} / \mathrm{min}$. The total amount of absorbed and injected ascites was $30-40 \mathrm{ml}$ per $\mathrm{kg}$ body weight of the dog.

Prior to autoreinfusion, a suitable fluid was considered to meet the following criteria:

Organoleptic studies. They included the definition of color, turbidity, viscosity of ascites and liquids. It should not contain significant impurities in blood, bits of fibrin, not to be cloudy, which may be observed as a result of inflammatory processes in the abdominal organs [11] .

Microscopic evaluation. For microscopy, an ascites liquid precipitate was obtained which was obtained by centrifuging it for 15 minutes at 2000 revolutions per minute. Initially, the sediment was investigated by the method of native drug. For a drop of sediment deposited on a glass slide and covered with cover glasses. Evaluated the total number of cells and their condition at small and large magnifications of the microscope. For a more accurate differentiation of the cell line, a drop of ascitic fluid was applied to the slide glass, dried in air, fixed for May-Grunwald, painted behind the Romanovsky-Gimse. The painted smear was microscopically immiscized and counted at least 100 cells. Evaluated the number of red blood cells, white blood cells, mesothelium cells [12 ]. Before autorefusion, an ascitic fluid was not allowed under the microscopy of a sediment which revealed more than 20-30 white blood cells in the field of view and a large number of mesothelial cells (more than 10\%) or the presence of tumor cells [13 ] .

Infusion of $10 \%$ human albumin was performed as an intravenous drop injection of $10 \%$ solution in the vein of the forearm.

Before the introduction of albumin to all animals, 5 dogs were given laparocentesis with the removal of ascitic fluid using the same technique as with its fence. Infusion rate was 2-3 ml per minute at a rate of $3 \mathrm{ml}$ per kg body weight of the animal [14]

As before and after the autorefusion of ascites fluid and 10\% human albumin infusion in all sick dogs the level of total serum protein was investigated using a semi-auto electrocolymeric biochemical analyzer StatFax (Awarness Technology, USA) with HUMAN reagents (Germany) by biuret method (Chromi V., 1977).

Operation were conducted under general anesthesia, what has been achieved combination $2 \%$ xylazine $(1 \mathrm{ml} / 15 \mathrm{~kg}$ ) and thiopental sodium ( $5-10 \mathrm{mg} / \mathrm{kg}$ ) with adherence all the rules of asepsis and antiseptics.

The animal fixed on the operating table in the dorsal position. Operative access to the spleen created by the way medial laparot of omeia. IN to the left hypochondrium palpated spleen and gently brought out her with an operational wound.

For the implementation of splenectomy, the gastric-splenic bond was applied and the required number of ligatures was calculated. For reliable ligation with minimal risk of ligature bleeding, ligatures were applied separately to each large vessel of the gastrointestinal ligament. Each of the selected vessels was superimposed on two ligatures at a distance of $2-3 \mathrm{~cm}$ apart. After they crossed the vessels with scissors between the ligatures and carried out a direct organ removal.

At the second stage of the surgical operation, the left kidney was lowered to the edges of the surgical wound and the longitudinal incision of the fibrous capsule was made. In the section, a zillard probe was introduced and for it, lifting the capsule, cut it out. Then the edges of the capsule were molded from the renal parenchyma. Fibrous capsule was not cut off. Then they cuffed the cuff of the spleen to the decapitated kidney, with the help of simple knotted stitches. As a suture material, polyamide was used.

After this, the abdominal wound was sewn by two-surface seams. All operated animals were prescribed to prevent wound infection - ceftriaxone $50 \mathrm{mg} / \mathrm{kg}$ per day for 7 days.

When we conducted conservative treatment was used a combination of simultaneously two diuretics different action.

The first of them was - spironolactone. Spironolactone is potassium preserving moderate diuretic sodium uretic effect . Diuretic effect spironolactone associated with it antagonism concerning the adrenal cortex hormone glands - aldosterone.

Action spironolactone it turns out to be distal kidney tubules : drug reduces breeding ions potassium and strengthens breeding ions sodium and water without significant violation electrolyte balance. Dose made up $1 \mathrm{mg} \backslash \mathrm{kg}$ per day . 
The second drug was selected - furosemide. Furosemide potent diuretic, effect whose develops quickly. The drug is a derivative sulfonamides. Mechanism actions furosemide associated with blockade of reabsorption ions sodium and chlorine in ascending Department loops Henle ; also affects the winding tubules, and moreover this the effect is not related from oppression carbohydrazides or aldosterone activity. The drug causes pronounced diuretic, natriuretic, chlorrhetic effect. Increases also breeding potassium , calcium, magnesium. The dose of the drug was $0.4 \mathrm{mg} / \mathrm{kg} 2$ times a day [15] .

Indicator the initial state of animals were evaluated on a zero day (day tion of operative intervention) at 10,30 and 90 day after surgery.

By criteria evaluation, we have taken the following Indexes, as the overall condition of the body is expressed ness manifestations ascites, duration life of dogs after surgical intervention or since the start of treatment .

For better visibility, we have developed a system for evaluating the above listed scores:

1. General condition of the dog : ( 1 - point is a dog feels bad does not show desire move, missing appetite ; 2 -points are a dog feels bad, partly saved appetite, moving reluctantly; 3 points - the condition of the dog satisfactory, appetite saved but weak ruhayet not be readily fast tired ; 4 points - a dog Feels good, appetite present, but with lasting walks quickly tired ; 5 points - the dog is well, there is an appetite, she is actively moving )

2. Severity of signs of ascites: ( 1 point - signs of ascites are severe, abdominal cavity and full of fluid is intense; 2 points - the signs of ascites are expressed, the stomach is lowered, not tense; 3 points - signs of ascites are poorly expressed, but it is possible to select an ascites fluid by laparocentesis ; 4 points insignificant manifestations of ascites, the fluid is found only after a thorough ultrasound examination; 5 points - signs of ascites are absent completely .

Our groups were formed on the principle of analogues so that the conditional average number of points in each group was approximately equal to 0 - day. Dogs who died in the subsequent assessment were not taken into account.

Table 1. Assessment of the condition of dogs in balls for 0 day ( weekend condition of dogs ) , $n=20$

\begin{tabular}{|c|c|c|c|}
\hline Criteria for evaluation & $\begin{array}{c}\text { The total number of } \\
\text { points is number } \mathbf{1}, \mathbf{n} \\
\mathbf{= 4}\end{array}$ & $\begin{array}{c}\text { The total number of } \\
\text { points group number } \\
\mathbf{2}, \mathbf{n = 1 1}\end{array}$ & $\begin{array}{c}\text { With a small number } \\
\text { of points group } \\
\text { number } \mathbf{3}, \mathbf{n}=\mathbf{5}\end{array}$ \\
\hline $\begin{array}{c}\text { General condition of } \\
\text { dogs }\end{array}$ & 2.5 & 2.72 & 2.8 \\
\hline $\begin{array}{c}\text { Expression of signs } \\
\text { of ascites }\end{array}$ & 2.25 & 2.36 & 2.4 \\
\hline
\end{tabular}

Table 2. Assessment of the condition of dogs in balls for 10 days, $n=15$

\begin{tabular}{|c|c|c|c|}
\hline Criteria for evaluation & $\begin{array}{c}\text { The total number of } \\
\text { points is number } \mathbf{1}, \mathbf{n} \\
\mathbf{= 4}\end{array}$ & $\begin{array}{c}\text { The total number of } \\
\text { points group number } \\
\mathbf{2 ,} \mathbf{n}=\mathbf{1 1}\end{array}$ & $\begin{array}{c}\text { With a small number } \\
\text { of points group } \\
\text { number } \mathbf{3}, \mathbf{n}=\mathbf{5}\end{array}$ \\
\hline $\begin{array}{c}\text { General condition of } \\
\text { dogs }\end{array}$ & 2.5 & 2.72 & 2.8 \\
\hline $\begin{array}{c}\text { Expression of signs } \\
\text { of ascites }\end{array}$ & 2.25 & 2.36 & 2.4 \\
\hline
\end{tabular}


Table 3. Assessment of the condition of dogs in balls for 30 days, $n=14$

\begin{tabular}{|c|c|c|c|}
\hline Criteria for evaluation & $\begin{array}{c}\text { Total number of points } \\
\text { group number 1, } \mathbf{n = 1}\end{array}$ & $\begin{array}{c}\text { The total number of } \\
\text { points group number 2 , } \\
\mathbf{n}=\mathbf{1 1}\end{array}$ & $\begin{array}{c}\text { The total number of } \\
\text { points group number 3, } \\
\mathbf{n}=\mathbf{3}\end{array}$ \\
\hline $\begin{array}{c}\text { General condition of } \\
\text { dogs }\end{array}$ & 2 & 3.09 & 3.33 \\
\hline $\begin{array}{c}\text { Expression of signs of } \\
\text { ascites }\end{array}$ & 3 & 2.81 & 2.3 \\
\hline
\end{tabular}

Table 4. Assessment of the condition of dogs in balls for 90 days, $n=11$

\begin{tabular}{|c|c|c|c|}
\hline Criteria for evaluation & $\begin{array}{c}\text { Total number of } \\
\text { points group number } \\
\mathbf{1}, \mathbf{n = 1}\end{array}$ & $\begin{array}{c}\text { The total number of } \\
\text { points group number } \\
\mathbf{2}, \mathbf{n = 8}\end{array}$ & $\begin{array}{c}\text { The total number of } \\
\text { points group number } \\
\mathbf{3}, \mathbf{n}=\mathbf{2}\end{array}$ \\
\hline $\begin{array}{c}\text { General condition of } \\
\text { dogs }\end{array}$ & 3 & 3.87 & 2.66 \\
\hline $\begin{array}{c}\text { Expression of signs } \\
\text { of ascites }\end{array}$ & 4 & 4 & 2.33 \\
\hline
\end{tabular}

In our opinion, separately trace to consider question during life dogs after surgical intervention or since the start of treatment .

Thus, during surgical intervention in the first group of dogs, which did not undergo preoperative correction of the total protein level of serum from 4 animals, 3 died, ie $75 \%$. Dogs died with signs of cardiovascular failure in the early postoperative period.

In our opinion, it is hypoproteinemia, an imbalance in the electrolyte composition of the blood, combined with the burden on the body by the introduction of anesthesia, the traumatization of the very surgical manipulation in general led to such a high mortality rate.

In the second group, compared with the first one, the correction was made for the level of the total protein of the serum, so the lethality of dogs in this group in the early postoperative period was significantly lower - 1 case out of 12 , which was $9 \%$. In the third control group, mortality was not noted in the time period that was equivalent to the early postoperative period of the stage.

Table 5. Mortality in dogs by groups , $\mathrm{n}=\mathbf{2 0}$

\begin{tabular}{|c|c|c|c|}
\hline $\begin{array}{c}\text { Days after the start of } \\
\text { treatment or surgical } \\
\text { operation }\end{array}$ & $\begin{array}{c}\text { Number of dead dogs } \\
\text { group } \\
\text { No1 } \\
\mathbf{n = 4}\end{array}$ & $\begin{array}{c}\text { Number of dead } \\
\text { dogs, group } \\
\text { No. 2 } \\
\mathbf{n = 1 1}\end{array}$ & $\begin{array}{c}\text { Number of dead dogs, } \\
\text { group } \\
\text { No. 3 } \\
\mathbf{n}=\mathbf{5}\end{array}$ \\
\hline $\mathbf{0 - 1}$ day & $3(\mathbf{7 5} \%)$ & $1(9 \%)$ & 0 \\
\hline $\mathbf{1 0}$ days & 0 & 0 & $1(20 \%)$ \\
\hline $\mathbf{3 0}$ days & 0 & 0 & $1(20 \%)$ \\
\hline $\mathbf{9 0}$ days & 0 & $2(18 \%)$ & $1(20 \%)$ \\
\hline
\end{tabular}

Accordingly, as of 90 days from the start of treatment alive remained in group $1-1$ dog ( $25 \%$ ), in group 2 - 8 dogs ( $73 \%$ ), in group 3 - 2 dogs ( $40 \%$ ).

In assessing the results of treatment of one of the first and important elements of which we had to face , it's pretty much mortality $(75 \%)$ in the first group of dogs, which were conducted without surgical correction of total protein blood serum. In our opinion, such an option should be avoid.

Under the surgical treatment of portal hypertension with ascites and use before operating the correction of the total protein levels were obtained much better results in the short postoperative period, mortality was $9 \%$ of the total number of operated dogs that demonstrates the advantages of this method.

In dogs, the third group of conservative treatment for 3 days lethality is not observed. Preference conservative treatment before surgery for this indicator was $20.3 \%$ at 10 days and $3.2 \%$ at 30 days. We believe this is due to the fact, that during this period have not yet formed splenorenal anastomoses of the vessels. Blood circulation on the site of omenenterenopecia is completely formed in the period from the 30 th to the 90th day, as evidenced by the dynamics of the curve of the effectiveness of surgical treatment 
compared with conservative treatment. Thus, the picture changed to 90 days and the break in percentage was $32.88 \%$ in favor of the first two methods of surgical treatment.

Dynamics mortality dogs showed the benefits of surgical treatment with preoperative correction of common blood proteins. Thus the gap on this indicator as of 90 days was compared to the first group of $48 \%$ compared to the third nd $33 \%$.

\section{Conclusions.}

1. Preoperative correction of the total protein in the blood of patients with ascites dogs before the surgeon treatment has a positive effect on the condition of the body in the early postoperative period, which is primarily manifested decrease mortality.

2. Surgical correction of portal hypertension and ascites using combined operation, which is simultaneous splenectomy and omentorenpexy, has an advantage over conservative treatment pits in the long run.

\section{Bibliography}

1. Vinnikov N.T. (2003). Veterinarnaja laboratornaja diagnostika. Saratov. P. 360. [In Russian].

2. Bosch J. Abraldes J.G., Groszmann R. (2003). Current management of portal hypertension. J. Hepatol. Vol. 38. P .54- 68.

3. Maslyakov B.B., Shapkin Ju.G. (2009). Selezenka i immunnyj status organizma [Spleen and immune status of the organism]. J. West. hir. №2. P.110 - 114. [In Russian].

4. An R., Kuritsin A.N., Pinchuk O.V. et al. (2002). Diagnostika i lechenie porazhenij selezenki v stacionare Garnizon [Diagnosis and treatment of lesions of the spleen in a hospital Garrison]. Military Medical Journal. № 6. P. 40-43 . [In Russian].

5. Bikhard K. (2005). Klinicheskaja veterinarnaja fpatofiziologija [Clinical Veterinary pathophysiology]. Moskva: Akvarium- print. 397 s. [In Russian].

6. Avtandilov G.G. (2002). Osnovy kolichestvennoj patologicheskoj anatomii [Fundamentals of quantitative pathological anatomy]. Moskva: Medicine. 237 s. [In Russian].

7. Yeramishantsev A.K. (2001). Khirurgicheskoe lechenie sindroma portal'noy gipertenzii $v$ Rossii [Surgical treatment of the syndrome of portal hypertension in Russia.] Ros. Journal of Gastroenterology, Hepatology, Coloproctology. №4. P. 75 -77. [In Russian].

8. Grzhimolovsky A.B., Karagyulyan S.R.,. Danishyan K.I. (2003) Laparoskopicheskaja splenektomija v gepatologii [Laparoscopic splenectomy in hematology]. J. Endoskop. hir. № 4. .35 s. . [In Russian].

9. Gentilini P., Vizzutti F., Gentilini A., Villa G. (2001). Ascites and hepatorenal syndrome [ascit i gepatorenal'nyj sindrom]. Eur. J. Gastroenterol . Hepatol. Vol. 13(4) P. 313-316.

10. Buzlama V.S. (2003). Veterinarnaja farmakologija segodnja i v budushhem [Veterinary Pharmacology: today and tomorrow] Sat. scientific. tr. Voronezh. T. 2. P. 176-178. [In Russian].

11. Dittrich S., Yordi L.M., Mattos A.A. (2001). Value of serum The ascites-albumin gradient for the determination of portal hypertension in the diagnosis of a scites [Znachenie syvorotki Gradient ascit-al'bumin dlja opredelenija portal'noj gipertenzii v diagnostike acscita]. J. Hepatogastroenterology . Vol. 48 (37). P. 166-168.

12. Denisenko V.N., Kesareva E.A. (2006). Diagnostika i lechenie zabolevanij pecheni u sobak [Diagnosis and treatment of hepatic diseases in dogs]. Moskva: Kolos. $63 \mathrm{~s}$. [In Russian].

13. Narwan H., Demes M., Kovac A., Danninger F. (2000). The Treatment of ascites with reinfiision of ascitic Fluid concentrate [Lechenie ascita s reinficirovaniem ascitnogo zhidkogo koncentrata]. Bratisl. Lek . Listy. Vol. 101(5). P. 306-309.

14. Heneghan M.A., Harrison C. (2000). Pathogenesis of ascites in cirrhosis and portal hypertension [Patogenez ascita pri cirroze i portal'noj gipertenzii]. Med. Sci. Monit. Vol. 6 (4). P. 807- 816.

15. Biryukov P.A., Yusupov I.A., Plekhanov V.I. (2006). Splenjektomija s omentorenopeksiej na fone portal'noj gipertenzii $v$ jeksperimente [Splenectomy with omentorenopeksiey on background portal noy hypertension in the experiment]. Success and modern science. №12. $43 \mathrm{~s}$. [In Russian]. 